\title{
MODEL KOMUNIKASI ANTAR BUDAYA KELUARGA MIXED MARRIAGE DI WILAYAH BUDAPEST-HUNGARIA
}

\author{
Zikri Fachrul Nurhadi, Heri Hendrawan, Desyya Fira Ayutria \\ Program Studi Ilmu Komunikasi, Peminatan Public Relations, Universitas Garut \\ Jln. Raya Samarang No. 52A Garut. \\ Telp. (0252) 544218 Email: zikri_fn@uniga.ac.id
}

\begin{abstract}
This study aims to discover the motives, experiences, meaning, and intercultural communication of mixed marriage couples in the Budapest-Hungary. The research uses phenomenology method Alfred Schutz and Husserl to examine the experience of people. Data are collected through observation, interviews through social media and literature study. The subjects are six mixed marriage couple living in Budapest-Hungary using purposive sampling technique. This research found a model of intercultural communication among mixed marriage couples related to motives, experiences, meanings, and intercultural communication based on cultural differences, languages, mindsets, as well as stereotypes of certain religions in which mixed marriage couples can adapt to the situation. This study contributes to four communication models of mixed marriage couples, namely motives, experiences, meanings and intercultural communication.
\end{abstract}

Key Words: Communication, Intercultural, Family, Mixed Marriage, Phenomenology

\begin{abstract}
Abstrak
Tujuan penelitian ini adalah untuk menemukan motif, pengalaman, makna atau komunikasi antar budaya yang dilakukan oleh pasangan keluarga mixed marriage di wilayah Budapest-Hungaria. Metode penelitian yang digunakan yaitu metode fenomenologi Alfred Schutz atau Husserl, yang mengkaji bentuk-bentuk pengalaman orang yang mengalaminya secara langsung. Sedangkan teknik pengumpulan data yang digunakan melalui observasi, wawancara melalui media sosial atau studi kepustakaan. Subjek pada penelitian ini adalah para pelaku mixed marriage sebanyak enam orang yang berdomisili di wilayah Budapest-Hungaria, dengan teknik purposive sampling. Hasil penelitian menemukan model komunikasi antarbudaya para pelaku mixed marriage terkait dengan motif, pengalaman, makna atau komunikasi antar budaya yang beragam yang didasari oleh banyaknya perbedaan budaya, bahasa, pola pikir, serta ditemukan stereotip terhadap agama tertentu namun para pelaku mixed marriage dapat beradaptasi dengan situasi tersebut.Penelitian ini memberikan konstribusi empat model komunikasi pelaku keluarga mixed marriage yaitu model motif, pengalaman, makna atau komunikasi antarbudaya pelaku mixed marriage.
\end{abstract}

Kata kunci: Komunikasi, Antar Budaya, Keluarga, Mixed Marriage, Fenomenologi

\section{Pendahuluan}

Pernikahan campuran yang dikenal dengan istilah mixed marriage merupakan hal yang umum terjadi di negara Hungaria. Hal ini, dilandasi oleh berbagai macam alasan, seperti banyaknya warga asing yang berkunjung atau bertempat tinggal di Hungaria dan warga Hungaria yang bermukim di luar negeri. Selain itu, lokasi negara Hungaria itu sendiri yang berada di wilayah Eropa Tengah, atau bertetangga dengan negaranegara lain juga mendukung terjadinya mixed marriage di negara tersebut. Budapest adalah ibu kota negara Hungaria. Kota seluas $525,16 \mathrm{~km}^{2}$ ini memiliki penduduk sebanyak 1.695 .000 jiwa dan dibagi menjadi 23 distrik. Kota ini merupakan penggabungan yang dilakukan pada tahun 1873 terhadap dua kota bersebelahan, Obuda (sisi barat) atau Pest (sisi 
timur), namun terpisah oleh Sungai Donau, kota Budapest adalah sebuah warisan dunia yang dilindungi oleh UNESCO mulai tahun 1987 (Budapest City Review, 2017). Romano (2008:43) menyebut fenomena Mixed Marriage dikenal dengan istilah pernikahan lintas budaya, pernikahan internasional, pernikahan antaretnis, hubungan antarbudaya, dan perkawinan campuran, yakni sebagai pernikahan yang dilakukan oleh dua orang individu yang mempunyai perbedaan budaya.

Berdasarkan hasil pengamatan empirik, fenomena mixed marriage di negara Hungaria telah berkembang atau menjadi hal yang biasa dilakukan. Fenomena pernikahan dengan negara yang berbeda, menghadirkan suatu hal yang luar biasa karena pihak-pihak terkait di dalamnya harus bertukar kebudayaan yang sangat berbeda. Kebudayaan yang sangat berbeda ini dapat mengganggu keharmonisan keluarga, karena disebabkan oleh stereotip dari masing-masing keluarga atau banyaknya budaya yang jauh berbeda (Hasil Pengamatan Peneliti, Agustus 2017). Banyaknya budaya yang jauh berbeda ini, menurut Lewis (2010: 46) pernikahan antarbudaya sangatunik, karena pasangan bersatu dalam ikatan pernikahan yang menghormati perbedaan nilai, norma atau sistem keyakinan hingga kebiasaan.

Terkait dengan realitas komunikasi antarbudaya keluarga mixed marriage, maka yang menjadi dasar masalah pada penelitian ini bahwa realitas perkawinan mixed marriage berada pada kutub yang berlawanan atau memiliki perbedaan yang tinggi, terutama pada aspek budaya. Perbedaan latar belakang budaya tersebut sangat memengaruhi cara pandang, pola pikir, bahasa serta sistem nilai yang dianut individu, sehingga perkawinan mixed marriage senantiasa membutuhkan penyesuaian diri dengan pasangannya. Perbedaan kebiasaan ini membawa tugas yang berat dalam sebuah perkawinan, bahwa perbedaan kebiasaan, norma atau sistem yang dianut membuat perkawinan antarbudaya mendekati kutub konflik (perceraian) (Nurhadi, 2016: 68).

Budaya yang berbeda, tentunya memiliki sistem nilai dan dapat menjadi salah satu penentu tujuan hidup yang berbeda pula. Konsekuensinya, pembendaharaan dua orang yang memiliki perbedaan budaya akan berbeda pula, hal ini dapat menimbulkan berbagai macam kesulitan (Romano, 2008: 34). Terkait dengan masalah yang muncul pada perkawinan mixed marriage, hal ini didukung oleh data mixed marriage di wilayah BudapestHungaria yang menggambarkan jumlah presentase cukup meningkat. Pada tahun 2009, presentase jumlah mixed marriage di Hungaria sebesar 19,3\% dari jumlah keseluruhan perkawinan di Hungaria. Pada tahun 2010 meningkat 1,3\% menjadi 20\%, tahun 2011 meningkat 1\% menjadi $21 \%$, pada tahun 2012 meningkat kembali sebesar 0,3\% menjadi $21,3 \%$ atau pada tahun 2013 terjadi peningkatan menjadi 24,2\% (Morgan, 2013: 243). Berdasarkan data jumlah mixed marriages yang terjadi di Hungaria, maka hal ini pula terjadi di Amerika Serikat, bahwa pernikahan antarbudaya disetujui secara legal sejak tahun 1867 (Seto, 2012: 258). Sedangkan jumlah pernikahan antarbudaya di negara Amerika Serikat terus berkembang. Pada tahun 1960 terdapat 
157.000 pernikahan, maka pada tahun 2010 angka itu melonjak tajam menjadi 2.413.000 (United States Bureau of the Census, 2012).

Menurut DeVito (2015: 53), komunikasi antarbudaya adalah komunikasi budaya yang memiliki perbedaan kepercayaan, nilai, norma sampai ke cara bertindak. Semua pesan berawal dari konteks budaya yang unik atau spesifik, atau konteks tersebut akan mempengaruhi isi atau bentuk komunikasi. Menurut Gudykunst atau Kim, 1997(dalamPratamawaty,dkk,2018: 700-701), menyatakan bahwa perkawinan lintas budaya lebih bermasalah daripada perkawinan antaretnik. Samovar, Porter dan McDaniel(2010:284), mengungkapkan bahwa banyak masalah yang diasosiasikan dengan pernikahan. Ketika dua orang dari dua budaya yang berbeda menikah, masalah yang mungkin timbul pun bertambah banyak. Berangkat dari paparan yang telah dijelaskan, hal inilah yang mendorong peneliti untuk melihat komunikasi antarbudaya menjadi sebuah topik yang terjadi dalam kehidupan keluarga mixed marriage. Tentunya, setiap pelaku perkawinan campuran pastinya memiliki motif, pengalaman, makna yang berbeda satu sama lain tergantung apa yang mereka ketahui sebelumnya tentang warga negara asing atau juga apa yang mereka inginkan dari perkawinan tersebut. Pengalaman-pengalaman yang dialami oleh setiap orang juga memengaruhi mereka dalam memaknai arti perkawinan campuran dalam budaya yang berbeda (Jolene, 2011:75).

Berdasarkan paparan tentang Komunikasi AntarBudayaDalamKeluarga Mixed Marriage di Wilayah Budapest-Hungaria, maka peneliti menggunakan teori fenomenologis sebagai pisau bedah dari Schutz bahwa tugas utama analisis fenomenologis adalah merekonstruksi dunia tentang kehidupan manusia "realitas sebenarnya" dalam bentuk yang mereka alami (Mulyana, 2008: 58). Dua fase yang diusulkan Schutz diberi nama tindakan in-order-to motive, yang merujuk pada masa yang akan datang dan tindakan (because-motive) yang merujuk pada masa lalu. Terkait dengan motif untuk Schutz selanjutnya menjelaskan bahwa melihat ke masa yang akan datang (lookingforward into the future) merupakan hal mendasar bagi konsep tindakan (Schutz dalam Kuswarno 2009: 110).

Motif karena (because-motive), dalam konteks fenomenologis, pelaku perkawinan campuran adalah aktor yang melakukan tindakan sosial bersama aktor lainnya sehingga memiliki kesamaan atau kebersamaan dalam ikatan makna intersubjektif. Husserl sendiri mendefinisikan fenomenologi sebagai pengalaman subjektif dan pengalaman fenomenologikal. Dalam arti yang lebih khusus, istilah ini mengacu pada penelitian terdisiplin tentang kesadaran (Pue, 2013: 269).

Penelitian ini diperkuat oleh hasil penelitian terdahulu yang diteliti oleh Puspowardani (2008: 45), tentang Komunikasi Antarbudaya dalam Keluarga Kawin Campur Jawa-Cina di Surakarta. Hasil penelitian terdahulu ini menggambarkan bahwa terdapat stereotip yang mempengaruhi penilaian keluarga terhadap seseorang yang dijadikan pendamping dalam kehidupannya. Begitu kuatnya hubungan kekeluargaan dalam etnis Cina, sehingga pendapat keluarga dijadikan pertimbangan serta diperlukan komitmen oleh pasangan kawin campur, sehingga bentuk kesalahpahaman lebih 
mudah teratasi. Begitu pun latar belakang setiap pelaku kawin campur, mempunyai pemikiran terbuka terhadap budaya yang dibawa oleh pasangannya, termasuk di dalamnya kepercayaan, nilai atau norma.

Berdasarkan penjelasan tersebut, maka yang menjadipertanyaan penelitian iniadalah bagaimana motif, pengalaman, makna atau komunikasi antarbudaya dalam keluarga mixed marriage? Penelitian ini bertujuan untuk menemukan model komunikasi terkait dengan motif, pengalaman, makna atau komunikasi antar budaya keluarga mixed marriage.

\section{Metode Penelitian}

Penelitian ini menggunakan metode fenomenologi, yang menggambarkan kepada sebuah pengalaman kehidupan para pelaku perkawinan campuran. Teori fenomenologi mempelajari tentang dunia kehidupan seperti yang biasa manusia alami, tanpa konsep, teori, atau kategori (Kuswarno, 2009: 26). Fokus metode penelitian ini secara rinci di lihat pada tabel 1 .

Tabel 1

Fokus Metode Penelitian

\begin{tabular}{|c|c|}
\hline Metode Penelitian & Keterangan \\
\hline Pendekatan Penelitian & $\begin{array}{l}\text { Pendekatan yang digunakan adalah pendekatan kualitatif sebagai metode } \\
\text { alamiah (natural setting). }\end{array}$ \\
\hline Paradigma Penelitian & $\begin{array}{l}\text { Paradigma penelitian menggunakan konstruktivis yang membahas tentang } \\
\text { pemahaman mengenai konstruksi makna perkawinan campuran di Wilayah } \\
\text { Budapest-Hungaria. }\end{array}$ \\
\hline Subjek Penelitian & $\begin{array}{l}\text { Subjek pada penelitian ini adalah suami dan istri keluarga mixed marriage } \\
\text { yang tinggal di wilayah Budapest, Hungaria. }\end{array}$ \\
\hline Teknik Penentuan Informan & $\begin{array}{l}\text { Teknik penentuan informan menggunakan purposive sampling yaitu peneliti } \\
\text { menentukan sejumlah informan sesuai tujuan atau maksud yang ingin dicapai } \\
\text { (salah satu peneliti menikah dengan warga negara Hungaria). }\end{array}$ \\
\hline Kriteria Informan & $\begin{array}{l}\text { 1. Informan merupakan suami dan istri keluarga mixed marriage yang tinggal } \\
\text { di wilayah Budapest, Hungaria. } \\
\text { 2. Suami dan istri dari keluarga mixed marriage yang telah menikah lebih dari } \\
2 \text { tahun. } \\
\text { 3. Aktivitas komunikasi sehari-hari keluarga mixed marriage. } \\
\text { 4. Dapat menjelaskan nilai dan kepercayaan yang dianut oleh kedua etnis. } \\
\text { 5. Suami dan istri memiliki warga negara yang berbeda dengan pasangan. }\end{array}$ \\
\hline Jumlah Informan & Jumlah informan pada penelitian ini sebanyak 6 orang. \\
\hline Teknik Pengumpulan Data & $\begin{array}{l}\text { Teknik pengumpulan data yang digunakan adalah observasi, wawancara } \\
\text { melalui media sosial, dokumentasi, atau studi kepustakaan. }\end{array}$ \\
\hline Teknik Analisi Data & $\begin{array}{l}\text { Teknik analisis data yang digunakan adalah pengumpulan data, reduksi data } \\
\text { atau penyajian data (Kuswarno, 2009: 43). Pengumpulan data yang dilaku- } \\
\text { kan melalui wawancara melalui media sosial, observasi lapangan. Reduksi } \\
\text { data yang dilakukan dengan cara mereduksi data-data yang diperoleh dari hasil } \\
\text { wawancara, sehingga data yang diperoleh memiliki kepastian atau keabsahan. } \\
\text { Sedangkan penyajian data dilakukan melalui penyajian data deskriptif dengan } \\
\text { memaparkan seluruh temuan-temuan melalui hasil penelitian terkait dengan } \\
\text { motif, pengalaan atau makna keluarga mixed marriage. }\end{array}$ \\
\hline
\end{tabular}


Berdasarkan fokus metode penelitian yang telah dijelaskan, maka langkah-langkah penelitian ini adalah, (1) Mencari informan sesuai dengan kriteria peneliti, kemudian melakukan komunikasi sebagai awal perkenalan atau penjelasan mengenai kesediaan dan ketidaksediannya menjadi informan peneliti untuk diwawancarai; (2) Membuat penjadwalan khusus dengan informan untuk melaksanakan wawancara mengenai suami dan istri keluarga mixed marriage; (3) Menjelaskan topik yang ditanyakan tentang keluarga mixed marriage kepada informan; (4) Melakukan wawancara untuk menggali informasi yang lengkap atau mendalam mengenai motif, pengalaman, makna atau komunikasi antar budaya; (5) Alur pertanyaan dalam mewawancarai informan, menggunakan pedoman (guide) wawancara sesuai kebutuhan dilapangan.

\section{Hasil Penelitian dan Pembahasan}

Pada bagian ini, peneliti akan menguraikan tentang aspek-aspek yang terkait Tabel 2

Model Motif Pelaku Keluarga Mixed Marriage dengan motif, pengalaman, makna serta komunikasi antar budaya pelaku perkawinan campuran yang berada di wilayah BudapestHungaria, yaitu:

\section{Motif Pelaku Perkawinan Campuran di Wilayah Budapest, Hungaria}

Berdasarkan hasil wawancara dengan informan, peneliti akan memaparkan keterkaitan penelitian ini dari segi motif sebuah perkawinan campuran yang terjadi di wilayah Budapest-Hungaria. Pada dasarnya, pelaku perkawinan campuran khususnya di wilayah Budapest-Hungaria didasari oleh adanya kekuatan yang mendorongnya baik dari dalam diri pelaku maupun dari luar. Berdasarkan hasil wawancara, peneliti mendapatkan hasil yang beragam mengenai motif terbagi dalam dua kategori jenis motif yaitu motif karena dan motif untuk. Hasil penelitian berdasarkan hasil wawancara dengan informan terkait dengan motif dapat dijelaskan pada tabel 2.

\begin{tabular}{|c|c|}
\hline Penjelasan Motif & Kategori \\
\hline $\begin{array}{l}\text { Motif Saling Mengenal. Motif informan menikah dengan warga negara asing adalah karena } \\
\text { merasa saling mengenal atau informan merasakan adanya ketertarikan dengan pola pikir yang } \\
\text { sama. }\end{array}$ & Because \\
\hline $\begin{array}{l}\text { Motif Ketertarikan. Jenis motif ini timbul karena memiliki kepribadian yang baik, cinta atau } \\
\text { kasih sayang serta adanya hubungan yang sudah disepakati. }\end{array}$ & Because \\
\hline Motif Trauma. Jenis motif ini ada rasa trauma dari informan yang menikah. & Because \\
\hline Motif Mempelajari Bahasa Asing. Jenis motif ini ketertarikan untuk mempelajari bahasa asing. & Because \\
\hline $\begin{array}{l}\text { Motif Memiliki Keyakinan yang sama. Jenis motif ini karena agama merupakan landasan } \\
\text { utama dalam sebuah pernikahan, sehingga berkeinginan untuk memiliki pasangan dengan } \\
\text { keyakinan yang sama. }\end{array}$ & Because \\
\hline $\begin{array}{l}\text { Motif Tantangan. Jenis motif ini pelaku memiliki sifat atau karakter hidup yang kuat, meski- } \\
\text { pun dengan budaya atau agama yang berbeda. }\end{array}$ & "in order to" \\
\hline $\begin{array}{l}\text { Motif Tinggal di luar Negeri. Jenis motif ini pelaku ingin menetap di satu negara yang bisa } \\
\text { membawa kenyamanan dalam kehidupannya. }\end{array}$ & "in order to" \\
\hline $\begin{array}{l}\text { Motif Kehidupan yang lebih baik. Jenis motif ini dipengaruhi oleh perceraian dengan war- } \\
\text { ganya, alasan menikah dengan WNI ingin memiliki kehidupan yang lebih baik. }\end{array}$ & "in order to" \\
\hline
\end{tabular}




\begin{tabular}{lc}
\hline \multicolumn{1}{c}{ Penjelasan Motif } & Kategori \\
\hline $\begin{array}{l}\text { Motif Mengayomi. Jenis motif ini dasarkan kepada faktor kedewasaan, sehingga dapat men- } \\
\text { jaga keharmonisan rumah tangga. }\end{array}$ & "in order to" \\
Motif Mengenal Dunia atau Budaya. Jenis motif ini dilatarbelakangi oleh maraknya peng- & "in order to" \\
gunaan media sosial. & \\
Motif Keturunan. Jenis motif ini informan ingin memiliki keturunan bule, tinggi, berkulit & "in order to" \\
putih, berhidung mancung atau menarik. & \\
Motif Sensasi. Jenis motif ini dilandasi adanya rasa romantik, respek atau saling mendukung. & "in order to" \\
\hline
\end{tabular}

Sumber: Hasil Kategorisasi Wawancara (Informan, 2017)

\section{Pengalaman Pelaku Mixed Marriage}

Berdasarkan hasil penelitian, para pelaku mixed marriage memiliki pengalaman yang menarik atau menyenangkan dalam menjalankan kehidupan sebagai keluarga mixed marriage. Keluarga mixed marriage ini dituntut untuk memahami sebuah kecocokan karena individu (pelaku) memiliki latar belakang yang berbeda. Pengalaman pasti akan terus ada, selama seseorang hidup. Begitu pun ketika dua orang yang baru saling mengenal dari negara yang berbeda, jelas sekali banyak perbedaan dari kebiasaan, aturan, pola pikir, bahasa, atau cara bertindak. Pengalaman pernikahan yang dikaji ini yaitu pengalaman para informan pelaku perkawinan Mixed Marriage di wilayah Budapest-Hungaria yang terlihat pada tabel 3 atau 4 .

Tabel 3

Model Pengalaman Positif Pelaku Keluarga Mixed Marriage

Berkeluarga dengan WNA
Menarik, banyaknya perbedaan budaya atau bahasa.
Bertemu orang-orang baru, atau adaptasi budaya serta
bahasa yang berbeda.

Mendapatkan teman atau relasi baru.

\section{Penggunaan Bahasa atau Adaptasi Lingkungan}

Menggunakan bahasa Hungaria untuk berkomunikasi sehari-hari.

Menggunakan bahasa Hungaria untuk berkomunikasi sehari-hari, adaptasi dengan lingkungan sekitar sangat mudah karena masyarakat yang mudah menerima warga negara asing.

Menggunakan bahasa Indonesia atau Hungaria dalam berkomunikasi.

Adaptasi sangat mudah dengan bertemunya teman atau relasi baru.

Mengenal budaya baru, adaptasi tinggal di negara asing.

Menggunakan bahasa Inggris dalam berkomunikasi, sosialisasi sangat menarik untuk dilakukan, masyarakat sangat ramah terhadap warga asing.

Perbedaan membuatnya belajar tentang toleransi, daKomunikasi sehari-hari menggunakan bahasa Hungaria, dapat beradaptasi dengan budaya yang berbeda. pat lebih mengenal budaya Indonesia, atau bertemu orang-orang dengan latar belakang budaya berbeda.

Mengenal lebih dalam mengenai Islam.

Menggunakan bahasa Inggris atau Hungaria dalam berkomunikasi.

Sangat mudah dalam beradaptasi karena warga sekitar yang terbuka dengan budaya atau warga negara asing. 
Tabel 4

Model Pengalaman Negatif Pelaku Keluarga Mixed Marriage

\section{Pengalaman Negatif}

Adanya perbedaan bahasa yang membatasi komunikasi dalam Mixed Marriage (Keterbatasan bahasa).

Biaya hidup di Hungaria jauh lebih mahal dibanding dengan Indonesia.

Jauh dari keluarga besar, sering terjadi perdebatan dalam membesarkan anak karena adanya perbedaan kebiasaan.

Sulitnya mendapat pekerjaan disebabkan oleh lapangan pekerjaan untuk English dan Indonesian speaker masih sempit.

Menyebabkan kesalahpahaman dalam berkomunikasi.

Adanya stereotipe terhadap muslim.

Sumber: Hasil Kategorisasi Wawancara (Informan, 2017)

Makna Mixed Marriage Bagi Pelaku

Makna merupakan bagian dari bentuk respon yang diperolah dalam sosialisasi. Makna yang dimaksud pada pelaku perkawinan mixed marriage dijelaskan pada tabel 5 .

\section{Komunikasi Antar Budaya Bagi Keluarga Mixed Marriage}

Komunikasi antarbudaya merupakan pembahasan yang sangat kompleks atau mendalam, terutama jika berada dalam konteks perkawinan campuran dan mixed marriage. Berikut ini adalah model komunikasi antarbudaya keluarga mixed marriage.

Hasil penelitian terkait dengan motif, pengalaman atau makna keluarga Mixed Marriage yang telah dijelaskan, maka dapat dijelaskan dalam bentuk bagan 1 kerangka konseptual.

Tabel 5

Makna Pelaku Keluarga Mixed Marriage

\begin{tabular}{|c|c|}
\hline Kategori Makna & Penjelasan Tentang Makna \\
\hline Tantangan atau Pembelajaran & $\begin{array}{l}\text { Perkawinan campuran dimaknai sebagai fenomena yang menarik, } \\
\text { menantang (unik) atau dijadikan pembelajaran. }\end{array}$ \\
\hline $\begin{array}{l}\text { Menghargai atau menghormati perbe- } \\
\text { daan }\end{array}$ & $\begin{array}{l}\text { Perkawinan campuran dimaknai sebagai perkawinan yang memi- } \\
\text { liki banyak perbedaan, saling menghargai, saling menghormati, } \\
\text { mengedepankan nilai-nilai toleransi. }\end{array}$ \\
\hline $\begin{array}{l}\text { Komitmen, persahabatan, kesempatan } \\
\text { untuk pemenuhan emosional }\end{array}$ & $\begin{array}{l}\text { Perkawinan campuran memiliki makna, menjadikan individu dan } \\
\text { pelaku memiliki jiwa komitmen, persahabatan atau pemenuhan } \\
\text { emosional. }\end{array}$ \\
\hline Perk & $\begin{array}{l}\text { vinan campuran dimaknai sebagai perkawinan yang indah } \\
\text { pengalaman baru. }\end{array}$ \\
\hline $\begin{array}{l}\text { Penggabungan atau pengenalan dua bu- } \\
\text { daya }\end{array}$ & $\begin{array}{l}\text { nan campuran terdiri dari dua negara yang berbeda budaya, } \\
\text { i sebagai penggabungan dua budaya. }\end{array}$ \\
\hline $\begin{array}{l}\text { Kompleks, butuh kesabaran atau pen- } \\
\text { gertian }\end{array}$ & $\begin{array}{l}\text { Perkawinan campuran lebih "kompleks", dibutuhkan kesabaran } \\
\text { atau pengertian lebih untuk menjalani atau mempertahankannya. }\end{array}$ \\
\hline Menyesuaikan perbedaan & $\begin{array}{l}\text { Perkawinan didasari oleh perbedaan cara berpikir atau bertindak se- } \\
\text { hingga perlu menyesuaikan diri dengan pasangannya. }\end{array}$ \\
\hline
\end{tabular}

Sumber: Hasil Kategorisasi Wawancara (Informan, 2017) 
Table 6

Model Komunikasi Antar Budaya Pelaku Mixed Marriage

\begin{tabular}{|l|}
\hline \multicolumn{1}{|c|}{ Komunikasi antarbudaya yang dilakukan } \\
\hline Keterbatasan bahasa \\
Adanya perbedaan agama \\
Kesalahpahaman berkomunikasi yang sering terjadi \\
Komunikasi dalam beradaptasi budaya berbeda \\
Komunikasi dalam mendidik anak \\
\hline
\end{tabular}

Sumber: Hasil Kategorisasi Wawancara (Informan, 2017)

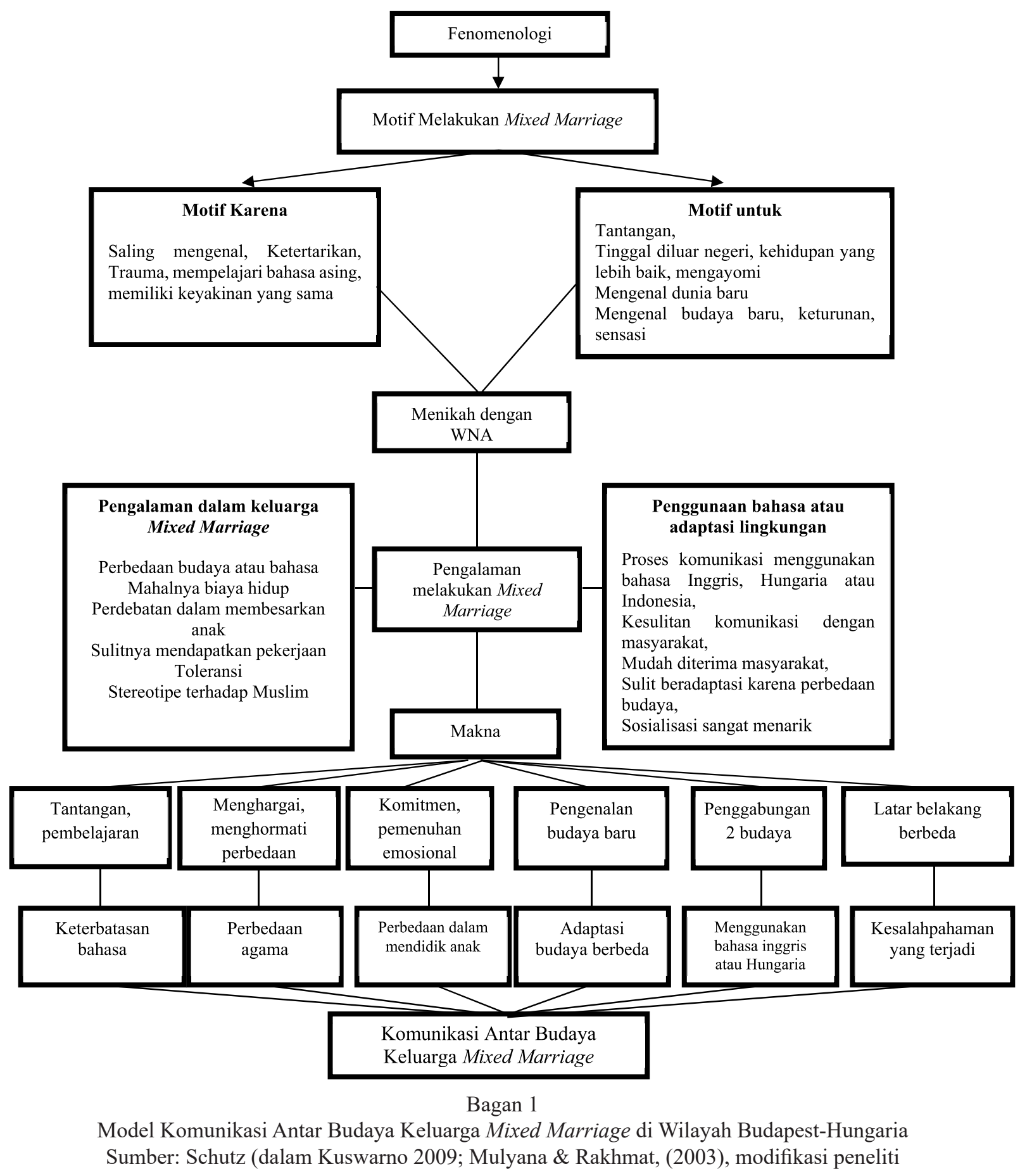


Hasil wawancara dengan informan yang dilakukan oleh peneliti, dielaborasikan dengan hasil wawancara dengan narasumber melalui proses triangulasi. Wawancara dilakukan dengan Farisa Rahmadhani sebagai Duta Besar Indonesia untuk negara Hungaria sebagai konsuler. Setiap pernikahan yang dilakukan di luar Indonesia oleh Warga Negara Indonesia, wajib didaftarkan di Kedutaan Besar Indonesia di Hungaria sebelum kemudian didaftarkan di catatan sipil di Indonesia agar pernikahan diakui atau dilegalkan oleh kedua negara. Maka dari itu sebagai konsuler kedutaan besar Indonesia, Farisa memahami benar mengenai pernikahan campuran yang dilakukan di wilayah Hungaria, yang menjelaskan bahwa banyak Warga Negara Indonesia (WNI) yang melakukan pernikahan dengan warga negara Hungaria maupun warga negara asing lainnya di Hungaria.

Motif yang muncul pada pelaku perkawinan campuran menurut Farisa adalah, biasanya mixed marriage terjadi kebanyakan karena beberapa warga Indonesia yang belajar atau bekerja di Hungaria atau menjalin hubungan dengan warga negara asing kemudian menikah. Era media sosial seperti saat ini juga mempengaruhi terjadinya mixed marriage. Lingkungan sosial juga mempengaruhi seperti pertemanan dengan orang asing di lingkungan pekerjaan. Alasan para pelaku mixed marriage menikah dengan warga negara asing kebanyakan dari mereka merasa tertarik dengan fisik warga negara asing. Hal tersebut diakui oleh sebagian beberapa warga negara Indonesia maupun asing lainnya yang menikah dengan pasangan yang berbeda kewarganegaraan. Hal senada sesuai dengan pernyataan Jones (2010: 15), faktor lainnya yang mendukung terjadinya mixed marriage adalah lingkungan kerja atau lingkungan sosial.

Pengalaman yang diungkapkan dalam keluarga mixed marriage menurut penjelasan Farisa adalah adaptasi lingkungan sosial atau tempat tinggal yang berbeda. Bersosialisasi di Hungaria, individu harus beradaptasi dengan cuaca yang jauh berbeda dari cuaca di Indonesia. Selain itu, kebanyakan dari para pelaku mixed marriage mengalami hambatan dalam berkomunikasi dengan warga sekitar karena keterbatasan bahasa. Hanya sekitar 30\% dari penduduk Hungaria dapat berkomunikasi dengan bahasa Inggris, sehingga hal tersebut membuat para pelaku mixed marriage harus belajar atau beradaptasi dengan bahasa baru.

Menurut narasumber, banyak pasangan mixed marriage memiliki anak, perlu dipertanyakan mengenai kewarganegaraan yang dimiliki anak-anak tersebut.. Narasumber menjelaskan bahwa berdasarkan peraturan pemerintah Hungaria anak tersebut mendapat dual citizenship, atau pemerintah Indonesia dapat memberikan kewarganegaraan ganda terbataskepadaanak daripernikahan campuran. Indonesia memberikan kewarganegaraan ganda terbatas sampai anak tersebut berusia 18 tahun atau setelah itu maka anak tersebut harus memilih salah satu kewarganegaraan (Venus, 2013: 32). Farisa juga menjelaskan bahwa komunikasi yang biasa dilakukan oleh pasangan mixed marriage yang baru menikah biasanya menggunakan bahasa Inggris dalam kehidupan sehari-hari. Setelah 
beberapa lama tinggal di Hungaria maka mereka akan mempelajari bahasa lokal dan mulai menggunakannya dalam berkomunikasi sehari-hari. Meskipun menggunakan bahasa yang sama, narasumber menambahkan bahwa tetap rentan terjadi kesalahpahaman yang diakibatkan perbedaan tradisi atau pemikiran. Masalah keterbatasan bahasa juga sering mengakibatkan kesalahpahaman dengan pasangan. Terlebih maraknya kasus terorisme yang terjadi, mengakibatkan stereotip mengenai Islam sebagai agama yang dianut sebagian besar Warga Negara Indonesia dapat mengakibatkan kesalahpahaman bagi pasangan mixed marriage yang memiliki perbedaan agama.

Begitupun makna yang dibangun pada pasangan mixed marriage yaitu menantang, kebiasaan berbeda, menghargai perbedaan, saling pengertian serta kompleks, sehingga dibutuhkan saling pengertian atau kesabaran yang lebih, dan dengan perbedaan yang beragam tersebut justru kehidupan menjadi lebih menarik dan berwarna. Ketika pasangan mixed marriage memaknai bahwa peristiwa perkawinan campuran merupakan bagian dari respon atau stimulus yang diperoleh melalui sosialisasi ataupun interaksi sosial. Hal ini senada dengan pendapat (Liliweri, 2018: 56), bahwa pemaknaan berkaitan erat dengan persepsi. Persepsi adalah pengalaman yang menjelaskan tentang situasi, peristiwa yang diperoleh dari pancaindra.

Berdasarkan hasil triangulasi data, maka peneliti dapat memberikan penguatan bahwa fenomena perkawinan campuran senantiasa membutuhkan penyesuaian diri dengan pasangannya. Komunikasi memainkan peranan yang penting untuk bagaimana beradaptasi dengan karakter, latar belakang budaya, penggunaan bahasa dalam komunikasi yang dilakukan antarpasangan menjadi sangat penting. Menurut Porter dan Samovar, 1982 (dalam Pratamawaty, dkk, 2018: 700), menjelaskan bahwa perbedaanperbedaan antara budaya Barat atau budaya Asia (Indonesia termasuk di dalamnya) merupakan contoh utama perbedaan budaya yang maksimum. Kedua budaya tersebut berada pada kutub yang berlawanan atau memiliki perbedaan yang tinggi. Perbedaan latar belakang budaya tersebut sangat mempengaruhi cara pandang, pola pikir, serta sistem nilai yang dianut individu.

Berdasarkan uraian yang telah dijelaskan bahwa kecenderungan melakukan pernikahan antarbudaya semakin menguat pada abad ke21. Hal ini disebabkan semakin banyaknya frekuensi orang yang melakukan perjalanan, pindah rumah, bersekolah, berwisata dan bekerja di luar negeri (Silva, 2017: 87). Lebih dari itu merebaknya media sosial semakin memudahkan orang membangun kontak tanpa dibatasi oleh jarak. Media ini juga memungkinkanmereka membangunhubungan yang bersifat personal (Venus, 2013: 36). Merujuk pada Seto (2012: 258), komunikasi merupakan faktor kunci dalam keberhasilan membina pernikahan antarbudaya, di mana pasangan bisa saling berbagi cara pandang atau berbagi makna untuk membangun pengertian bersama (common meaning) diantara suami istri. Sebaliknya, tanpa berbagi perspektif, pasangan dapat mempersepsi peristiwa dan situasi secara berbeda kemudian akhirnya menghambat proses saling mengerti. 
Apabila ini terjadi maka stres terhadap perkawinan antarbudaya akan muncul dan akan menurunkan kualitas hubungan dalam perkawinan meski berbeda budaya (Schrift, 2015: 347).

Hal ini, senada dengan pernyataan Liliweri (2018: 43), yaitu nilai sosial atau nilai budaya keluarga kawin campur akan sangat tampak ketika masuk dalam konteks penyelesaian persoalan atau konflik. Setiap pasangan berusaha mengambil keputusan dalam pemecahan masalah tidak berlandaskan keputusan emosional pribadi berlatar budaya, melainkan keputusan rasional yang dapat digunakan sebagai jalan keluar. Hasil penelitian lain juga menjelaskan bahwa komunikasi perkawinan antarbudaya selama sepuluh tahun terakhir, seperti dilakukan Bedner (2010: 176), diarahkan untuk mengetahui aspek-aspek komunikasi yang dianggap mampu mengatasi perbedaan budaya atau meningkatkan kualitas hubungan pasangan berbeda budaya.

Romano (2008: 83) menyebutkan delapan aspek komunikasi yang perlu ada dalam pernikahan antarbudaya yang meliputi kemampuan berempati, kesabaran, kesediaan memahami, empati, penyesuaian diri, fleksibel, toleran, atau keinginan untuk mengekspresikan pendapat atau ekspektasi diri terhadap pasangan. Hal ini, juga diperkuat oleh hasil penelitian Karel (2014: 92) yang menjelaskan bahwa terdapat dua indikator bagi proses penyesuaian dalam perkawinan beda agama dan budaya, yakni keberhasilan penyesuaian dalam perkawinan tidak ditandai dengan konflik yang terjadi, penyesuaian dalam perkawinan tidak ditandai oleh sikap atau cara yang konstruktif dalam melakukan resolusi konflik.

\section{Simpulan}

Kesimpulan pada penelitian ini, memberikan kontribusi terkait dengan model komunikasi antarbudaya keluarga Mixed Marriage terkait dengan:

Motif informan sebagai pelaku mixed marriage karena mereka merasa cocok atau atas dasar cinta. Terdapat pula motif lain yang melatar belakangi terjadinya mixed marriage seperti menarik atau menantang, sehingga ada kebanggaan tersendiri yang dirasakan oleh para pelaku mixed marriage. Pengalaman pelaku mixed marriage selama menikah dengan warga negara asing memiliki permasalahan utama dalam hal bahasa, beberapa informan mengalami kesulitan beradaptasi karena keterbatasan bahasa. Selain itu, adanya stereotip yang mengganggu keharmonisan dalam keluarga mixed marriage. Terdapat pengalaman positif diakui oleh informan bahwa mixed marriage adalah proses pembelajaran dari pengalaman yang menyenangkan. Para informan memaknai mixed marriage sebagai pernikahan yang dapat memberikan pembelajaran dalam bertoleransi, menghargai atau menghormati setiap perbedaan budaya masing-masing pasangan, atau perbedaan latar belakang. Toleransi ini dilakukan untuk menjaga keharmonisan dalam keluarga mixed marriage. Komunikasi antar budaya pada keluarga mixed marriage, terasa menarik atau menantang untuk dilakukan karena adanya perbedaan budaya, kebiasaan, pola pikir, serta perbedaan agama. 
Substansi penelitian ini memberikan saran dan masukan kepada pelaku atau orang yang akan melakukan pernikahan serupa, diharapkan untuk menjalin perkenalan yang tidak dilakukan secara singkat terkait dengan perbedaan karakter, budaya atau agama dari masing-masing pasangan. Banyaknya perbedaan yang akan dihadapi setelah menikah, maka dibutuhkan saling pengertian atau saling menghargai kebudayaan pasangan. Hal terpenting dari perkawinan campuran adalah jadikan segala sesuatunya berlandaskan atas ajaran atau aturan agama. Saran kepada peneliti selanjutnya, secara tegas menggali kembali dalam aspek perilaku komunikasi yang penting dipelajari untuk keberhasilan sebuah komunikasi perkawinan yang berlatar antarbudaya.

\section{Daftar Pustaka}

Bedner, A. \& Van Huis, S. (2010). Plurality of Marriage Law And Marriage Registration For Muslims In Indonesia: A Plea For Pragmatism. Journal Utrecht Law Review. 6(2), 175-191.

DeVito, J. A. (2015). The Interpersonal Communication Book. Edisi Ke-14. New York: Longman.

Jones, G \& Shen, Hsiu-hua. (2010). International marriage in East and Southeast Asia: Journal trends and research emphases. Citizenship Studies, 12(1), 9-25.

Jolene, Koester. (2011). Intercultural Competence: Interpersonal Communication Accros Cultures. USA: Allyn And Bacon.

Karel, Rivika, Sakti, dkk. (2014). Komunikasi Antarpribadi Pada Pasangan Suami Istri Beda Negara. Journal Acta Diurna, Volume III Nomor 4, 2014, Hal. 1-14.

Kuswarno, Engkus. (2009). Fenomenologi. Bandung: Widya Padjajaran.
Lewis, R, Jr \& Ford, Robertson, J. M. (2010). Understanding The Occurrence Of Interracial Marriage In The United States Through Differential Assimilation. Journal of Black Studies, 41, 10-24.

Liliweri, Alo. (2018). Prasangka, Konflik atau Komunikasi Antarbudaya. Edisi kedua. Jakarta: Prenada Media Group.

Pue, G. H., \& Sulaiman, N. (2013). “Choose One!": Challenges of Inter-Ethnic Marriages in Malaysia. Journal Asian Social Science, 9(17), p 269.

Morgan, Charlie V. (2013). Intermarriage Across Race and Ethnicity Among Immigrants. Journal of Comparative Family Studies, 35(5), 243.

Mulyana, Deddy. (2008). Ilmu Komunikasi, Suatu Pengantar. Bandung: Remaja Rosdakarya.

Nurhadi, Zikri Fachrul \& Yandini, Sheila. (2016). Konstruksi Makna Perkawinan Campuran Bagi Perempuan Muslim Indonesia.Jurnal Penelitian Komunikasi, Volume 19 Nomor 1, Juli, Hal. 83-94.

Pratamawaty, Benazir, Bona, dkk. (2018). Model Konstruksi Makna Peran atau Posisi Perempuan Indonesia Pelaku Kawin Campur. Jurnal Komunikasi ASPIKOM, Volume 3 Nomor 4, Januari, Hal. 700-711.

Puspowardani, Rulliyanti. (2008). Komunikasi antar budaya dalam keluarga kawin campur Jawa-Cina di Surakarta. Tesis. Program Studi Ilmu Komunikasi, Program Pascasarjana. Universitas Sebelas Maret.

Romano, Dugan. (2008). Intercultural Marriage, Promises and Pitfalls. Journal of Social and Cultural Family Studies, 29(8), 342-354.

Samovar, Larry, A \& Richard, E, Porter. (2010). Cultural Factors That Influence Early Marriage. Journal Social Science, 35, 80-91. 
Silva, L. C, Campbell, K, \& Wright, D. W. (2017). Intercultural Relationships: Entry, Adjustment, and Cultural Negotiations. Journal of Comparative Family Studies, 43(6), 857-870.

Schrift, R. (2015). Intermarriages and Interethnic Relations. Journal Ethnic and Racial Studies, 1(4), 345-358.
Seto, A. (2012). Cross-National Couples in the Mailand United States. The Family Journal. 15, 258.

Venus, Antar. (2013). Fenomenologi Komunikasi Perkawinan Antarbudaya. Jurnal Ilmu Komunikasi, Volume 2 Nomor 2, September, Hal. 1-14. 